1991

\title{
Two Views of Collective Rights
}

Leslie Green

Osgoode Hall Law School of York University

\section{Source Publication:}

Canadian Journal of Law and Jurisprudence. Volume 4, Number 2 (1991), p. 315-328.

Follow this and additional works at: https://digitalcommons.osgoode.yorku.ca/scholarly_works cc) (i) $\Theta \Theta$

This work is licensed under a Creative Commons Attribution-Noncommercial-No Derivative Works 4.0 License.

\section{Recommended Citation}

Green, Leslie. "Two Views of Collective Rights." Canadian Journal of Law and Jurisprudence 4.2 (1991): 315-328.

This Article is brought to you for free and open access by the Faculty Scholarship at Osgoode Digital Commons. It has been accepted for inclusion in Articles \& Book Chapters by an authorized administrator of Osgoode Digital Commons. 


\title{
Two Views of Collective Rights
}

\author{
Leslie Green
}

In this paper, I distinguish two views of collective rights, viz., rights of collective agents and rights to collective goods. My argument is that although both have a place in moral, political and legal argument, only the second can fulfil the political function generally assigned to collective rights, and that even it can do so only partially.

\section{Rights and Individualism}

An account of collective rights may be wanted for different purposes. First, we may seek a tool for the description and analysis of the variety of rights held under conventional normative systems. Many institutions, including legal systems, accord and recognize the rights of entities other than individual human beings: business corporations, trades unions, political parties, and states are only some of the groups that have rights in law; and our conventional morality sometimes recognizes rights of groups such as families, nations, and churches.

It is true that some theorists have expressed general scepticism about collective rights, denying that the notion is a coherent one. I think that makes it very hard to understand the legal and customary rights mentioned above. There is, of course, plenty of room for dispute about how exactly they are to be analyzed, what weight they have, and so on. But it is too late to protest that only individual people are actually recognized as having rights.

In fact, general scepticism about collective rights is more often political than it is metaphysical. It is grounded, not in doubts about the reality of nonindividual actors or the extent to which they are recognized in law or custom, but in worries about their moral or political standing. Evidence in favour of this is the fact that there is no comparable doubt about the existence of collective duties. Most people who believe in individual rights also believe that collective agents such as governments and corporations can be subject to duties correlative to those rights. They have, for example, little trouble supposing that the government has a duty not to abridge freedom of expression, or to secure and facilitate political participation, and so on. Collective rights are not as favourably regarded simply because many people endorse first-order normative views according to which the interests of individual people are of over-riding importance and that individuals should not bear duties for the sake of collectivities.

Now this brings us to the second and, for present purposes, more important motivation for talk of collective rights. They are often invoked with the express political function of mitigating the individualism that many think is latent in rights. 
The supposed individualism of rights is remarked on, not only by their critics, but also by their friends.' Yet what the charge amounts to and how might it be avoided are complex matters, for 'individualism' is not an easy concept in political theory. Some take it to mean that rights encourage egoism and promote social conflict. Those charges are easily rebutted without introducing collective rights at all. As Jeremy Waldron correctly notes ${ }^{2}$ moral rights are'universal in form; they apply to anyone situated in a certain way, so it is neither incoherent nor odd for people to defend, non-egoistically, the rights of others. Moreover, rights typically protect a range of possible actions and that normally includes both egoistic and non-egoistic alternatives. The right to a sum of money entitles one to spend it on oneself or give it to charity; the right does not recommend acting only for one's own advantage.

The second charge, that rights promote social conflict, is no stronger. Hegel thought that arguments about rights can betray a narrowness of moral outlook: "it is uncultured people who insist most on their rights, while nobler minds look on other aspects of the thing,"3 he wrote. Some writers associate this with the idea that rights are the legalistic part of morality ${ }^{4}$ and believe that to endorse rights is therefore to be litigious. This merely repeats the error of the first charge in new form; it is no part of the nature of rights that they must be insisted on. No doubt there are points at which agents should transcend attention to their own rights and think in the broader terms of the common good, or civic virtue, or whatever. But having rights does not prevent them doing so. Once again, the complaint mistakes the function of rights and therefore incorrectly draws a connection between rights and social conflict. Having a right does not give one any reason to exercise it, let alone insist on it.s Of course, if people are contentious to begin with, they can be expected to use institutionalized rights in their defense and nothing in those rights will force them to change their character. However, it is not the function of rights to effect that transformation, and it is a poor argument that blames rights for failing at a task that is not their own. This is not to deny that rights are as open to abuse as any other concept in political morality. In our own political culture, for example, hateful speech is sometimes defended by the speaker on the grounds that he or she has a right to free expression. But that makes about as much sense as it would to appeal to the right to personal liberty to justify

1. E.g., J. Mackie, "Can There be a Right-Based Moral Theory?" in J. Waldron, ed., Theories of Rights (Oxford: Oxford University Press, 1984) 168 at 179: "It may be asked whether this theory is individualist, perhaps too individualist. It is indeed individualist in that individual persons are the primary bearers of rights, and the sole bearers of fundamental rights, and one of its chief merits is that, unlike aggregate goal-based theories, it offers a persistent defence of some interests of each individual."

2. J. Waldron, ed., Nonsense on Stilts: Bentham, Burke and Marx on the Rights of Man (London: Methuen, 1987) at 190-209.

3. G.F.W. Hegel, The Philosophy of Right, trans. T.M. Knox (Oxford: Clarendon Press, 1945) at 235 (addition to para. 37).

4. Thomas Reid took an extreme view of this. He held that the concept of a right is "too artificial to be the birth of common language. It is a term of art contrived by civilians when the civil law became a profession." Thomas Reid, Essays on the Active Powers of the Human Mind (Cambridge, Mass.: MrT Press, 1969) at 379.

5. As Hegel recognized: "to have a right gives one a warrant, but it is not absolutely necessary that one should insist on one's rights, because that is only one aspect of the whole situation." Supra. note 3 at 235 . 
standing on one's head while awaiting the bus. The existence of the right directs others how they may respond to the agent's choices; it gives the agent no ground for choosing one way rather than another. Interesting work remains to be done in explaining the origin and power of these errors. Still, ideological mistakes, however popular, are not to be ratified at the level of theory.

There are, nonetheless, other affinities between doctrines of rights and at least some forms of ethical individualism. To isolate these, we need to take a closer look at the specific nature of rights. I believe that a plausible general definition can be developed along the lines suggested by Joseph Raz:

' $X$ has a right' if and only if $X$ can have rights and, other things being equal, an aspect of X's well-being (his interest) is a sufficient reason for holding some other person(s) to be under a duty. ${ }^{\circ}$

On this view, rights are not merely correlated with duties on the part of others; they are the grounds of those duties.' Duties may be argued for in various ways, only some of which reflect a commitment to rights. One may have a duty which is grounded in the public interest or in the will of a god. Even when these duties produce benefits for others, they are not correlated to rights except when the argument for the existence of a duty is based on an appeal to the interests of the right-holder.

When specified in this way, it may seem that political and moral arguments invoking rights must be individualistic ones. Thus Waldron writes:

By its very nature, a theory of rights is an individualistic theory: Rights purport to secure goods for individuals: that is an elementary consequence of their logical form. A right is always somebody's right, and we never attempt to secure things as a matter of right unless there is some individual or individuals whose rights are in question."

But there is more to it than this formal truth. Although a right is always somebody's, the somebodies are generally taken to be individuals and the interests worth protecting in this way are usually taken to be the familiar divisible interests in liberty, personal security, and so forth that are so prominent in classical liberal theory. It is at this point that the alliance between theories of rights and individualism seems strongest, for urgent as these individuated interests are, they do not exhaust what is important in life. Much that is worthwhile is intimately bound up with cooperative activity. Liberty is important, but so is a sense of common enterprise. Security is valuable, but so is the kind of fellowship expressed in shared political institutions. Moreover, while individual well-being matters, so may the well-being of groups of people, especially when it seems distinct from the well-being of their members taken severally.

Those are the sort of concerns that often motivate talk of collective rights. Believing that they have not been given their due by traditional doctrines of

6. J. Raz, The Morality of Freedom (Oxford: Clarendon Press. 1986) at 166.

7. I draw no distinction between duties and obligations. The definition provides an analysis of chaim rights but can be extended in obvious ways to cover other forms of normative protection. such as immunities.

8. Waldron, supra, note 2 at 185. 
individual rights, it is often argued that they form the basis for collective rights. Why appeal to rights at all here? The motivation is simple. Rights ground duties, and duties have peremptory force: they establish what one must do, not merely what it would be nice or desirable to do. To argue in favour of some practice that it would protect one's rights, or against it that it would violate them, therefore appears to have an urgency lacking in appeals to the public interest, or the common good, or nobility of character. Now this assumption may be wrong, but it is certainly widespread. Even J.S. Mill, whose morality was founded on a particular conception of the public interest, held that matters of justice and rights concern the most urgent kind of utility. Rights signal degrees of urgency among moral considerations, and theories of rights therefore appear to elevate their subject matter above the rest of morality. Those who defend collective rights want to capture this urgency for the sort of moral concerns mentioned above. By thus widening the scope of rights-based arguments they seek to widen their appeal. Those who fear that rights are too individualistic may therefore be attracted to arguments purporting to show that, in addition to these peremptory individual concerns, there are also peremptory collective concerns, with the result that one must sometimes 'balance', as the metaphor has it, the rights of individuals and the rights of groups.

\section{Rights of Collective Agents}

That picture captures, though no doubt in a simplified way, much enthusiasm for collective rights. I now want to consider the form that enthusiasm takes. Some who feel the attraction of such arguments assume that they must show that collective rights are the rights of collective agents, that collective agency is coordinate with the moral concerns they feel are being unreached.

This way of conceiving of collective rights sees the matter as turning on the capacity conditions of right-holders. Nothing has rights that is not capable of having rights; so the question of whether there are any collective rights depends on whether any non-individuals have the requisite capacity. Structurally, the question whether any collectivities have rights is thus like the question whether any non-human animals have rights: each can be settled only by appeal to a substantive theory of moral agency.

Wayne Sumner is among those who think that there may be collective rights in this sense of the term. He argues:

the capacity of agency is a logical pre-condition of having rights. But every social group which qualifies as either an institution or an association must have some procedure for reaching collective decisions and taking collective action. (...) collectivities will qualify as the subjects of rights as long as they possess the requisite capacity to act on behalf of their members.

There are at least two items on Sumner's agenda here: one is to endorse a capacity conception of collective rights, the other is to suggest that this

9. L. W. Sumner, The Moral Foundation of Rights (Oxford: Clarendon Press, 1987) at 209. 
conception is more at home with the so-called 'choice' theory of rights than it is with the 'interest' theory that I have accepted here. I want to pause for a moment over the second.

According to the choice or will theory, the essence of rights is to provide normative protection for the exercise of certain choices. They demarcate areas in which, as H.L.A. Hart puts it, individuals can act as small-scale sovereigns. Sumner's argument depends on the claim that, while it is easy to make sense of collective action as distinct from the separate activities of the collectivity's members, it is more difficult to conceive of collective interests that are not just the sum of individual interests. This alleged asymmetry is, however, less significant than Sumner thinks. Collective choice mechanisms (voting, markets, etc.) of the usual sorts are in fact functions of individual choices. We say that a certain function of individual choices, say, majority rule, counts as the group's decision. Similarly, a certain function (not necessarily a sum) of individual interests could count as the collective interest. It is hard to see why the former but not the latter is sufficiently different from its individual components to ground a distinctive sort of rights.

Moreover, it is open to doubt whether the choice theory really is a competing general account of rights at all, as opposed to a special substantive view about what sort of interests warrant holding others duty-bound. At least some choice theorists could accept the general definition of rights endorsed here and argue that freedom of choice with respect to certain actions is the interest uniquely worth protecting. I shall therefore by-pass that dispute entirely and focus on the main question of whether collective agents can be the bearers of rights.

Could corporations, ethnic groups, nations, states, churches, etc. have the capacity to be right-holders? We would need to ask whether it is possible to see some concept of well-being as applying to these entities, and whether it provides a reason for holding others to be bound by duties. It is important here to be able to distinguish the rights of a collective agent from a set of individual rights. If the Mohawk nation has the collective right to self-determination then it must amount to something more than the set of rights of individual Mohawks to associate freely, organize for autonomous political institutions, and so on. All of that can be effortlessly put in the idiom of the classical individual rights to freedom of association, political participation, and so on.

In one way or another, most writers feel that this involves some kind of irreducibility thesis, for example, a commitment to social holism. They say that a nation can fare well or ill in ways independent of the welfare of its members, that it can act in ways not reducible to individual actions, that it has an organic and not merely mechanical unity, and so forth. On this view, the more nearly the Mohawk nation can be understood as being like individual Mohawks, the more likely that it has the capacity to be a right-holder.

Having defended a conception of collective agency and well-being, one must then go on to show that these can give rise to the sort of considerations that warrant holding others duty-bound. That is a separate step too often ignored by enthusiasts of collective rights. Consider an example. Suppose one considers French Quebec to be a collective agent with the appropriate 
capacities. ${ }^{10}$ One aspect of its well-being might plausibly be said to be its survival as a distinct culture. That will not itself show that French Quebec has a collective right to survive, as opposed to it being a good thing that it survive, for we have not yet shown that survival of this agent is something for the sake of which anyone ought to be held duty-bound. Linguistic survival is threatened primarily by assimilation, exogamy, migration, and a declining birth rate. But if individual Quebeckers are deciding not to have children, or to marry out of the language group, or to teach their children English, then they will be the primary bearers of the duties that the right to survival grounds. Even if the nation has its own interests, these do not seem urgent enough to warrant holding its members duty-bound to promote them.

Compare this to the situation of the Mohawks. Their collective right to selfdetermination imposes duties on others, principally on the people and governments of Canada and Quebec. Those duties are justified by the interests of the Mohawk nation, not by the interests of individual Mohawks taken severally. Here the argument to collective rights may proceed more smoothly, for it is not too difficult to see why the interest in self-determination might ground duties for others. My claim is not that there is always a collective right to self-determination but never to cultural survival. It is that on this first view of collective rights, establishing the existence of an agent with the appropriate capacity is a necessary but not sufficient condition of having rights. In some cases, the interests of the collective agent may ground duties; in others it may not.

\section{Rights to Collective Interests}

Whereas the first view of collective rights focuses on the capacity condition, the second focuses on the benefit condition of rights. On this view, collective rights are distinguished not by the sort of agents they protect, but by the sort of interests they protect.

We can clarify the distinction by returning to Sumner's scepticism about collective well-being. Suppose that one cannot conceive of the well-being of French Quebec as distinct from the well-being of French Quebeckers. If that is indeed inconceivable, then it rules out the rights noted above: there can be no collective interest in survival that it is at variance with the interest of individual Quebeckers. It is always a bit hard to evaluate appeals to conceivability. Here, I would like to broaden the philosophical imagination a little. If individual rights are grounded in individual interests then, by analogy, collective rights are grounded in collective interests. But what are collective interests? The view outlined in Section 2 supposes them to be the interests of collective agents. To establish the existence of such rights we therefore need to show that there are such agents, that they have distinct interests, and that these interests are sufficiently urgent to warrant holding others duty-bound. There is, however,

10. This is an interesting case for Sumner's theory, since it seems easier to give an account of the collective well-being of French Quebec than it is of its powers of collective choice. (The notion that the legislature of Quebec acts only for French Quebec is a nationalist conceit.) 
another way to understand the notion of collective interests. Instead of supposing that they are the interests of collectivities, we might instead think of them as interests of individuals that have a collective aspect.

Individuals have at least two kinds of collective interests in this sense. First, they have an interest in what economists call public goods. These are goods that are inexcludable and non-rival in consumption: if they are available for some then there is no convenient way to prevent others from also receiving them, and the quantity consumed by one person does not perceptibly limit the level of consumption by others. Because of the notorious free-rider problem, public goods are often not optimally supplied (and sometimes not supplied at all) by voluntary mechanisms such as the market. An interest that one has in a public good is an interest that is, for reasons tied to its production, held in common with others.

Second, there are also what I have elsewhere" called shared goods, which are like public goods except that their public aspect is not merely a contingent feature of their production but partly constitutes what is valuable about them. Friendship is clearly among the things that are good for individuals and it is a joint effort. But this feature of its production is ill-understood if we think of it as being like the kind of collective endeavour that is undertaken to supply, for example, national defense. National defense is a good the character (though not the quantity) of which is invariant with respect to its means of production. Quantity aside, it is normally a matter of indifference whether it is, say, supplied individually through a market mechanism or collectively through conscription and taxation. With respect to friendship, however, things are quite different. It is a constitutive feature of friendship that it is jointly produced; individuated supply is not merely inefficient, it is impossible.

Interestingly, most classical accounts regard both kinds of interests as inappropriate grounds of rights. There is, however, considerable uncertainty as to just why this is so. One line of argument supposes that, for the interest-duty nexus to be made out, interests must be fully individuated. According to J.S. Mill, for example, one violates a right only when one breaches "distinct and assignable obligations" owed to others and not when one does "merely contingent, or, as it may be called, constructive injury ... to society."12 This might be taken to suggest that the realm of rights is the realm of private goods.

Recently, Neil MacCormick argues that legal rules that confer rights "concern the enjoyment of goods by individuals separately, not simply as members of a collectivity enjoying a diffuse common benefit in which all participate in indistinguishable and unassignable shares."'3' He later elaborates:

When positive laws establish rights, for example expressly by legislation. what they do is secure individuals (or members of a particular defined set of individuals) in the enjoyment of some good or other. But not by way of a collective good collectively enjoyed, like clean air in a city, but rather an individual good individually enjoyed by

11. L. Green, The Authority of the State (Oxford: Clarendon Press, 1988) at 206-09.

12. J.S. Mill, On Liberty, ed. by M. Wamock (London: Fontana, 1962) at 212-13.

13. D.N. MacCormick, "Rights in Legislation," in P.M.S. Hacker J. Raz, eds, Low: Moralin, and Society: Essays in Honour of H.LA. Hart (Oxford: Clarendon Press, 1977) 189 at 205. 
each, like the protection of each occupier's particular environment as secured by the law of private nuisance. ${ }^{14}$

It may be significant that MacCormick's claim is restricted to legal rights. This special context does complicate matters somewhat; the need for clear rules governing standing may create some practical pressure for a legal system to restrict rights in this way. But positive law can be changed, and in different jurisdictions these matters are handled in different ways. So it is helpful to ask whether there is any deeper objection to recognizing rights to collective goods in moral and political discourse in general.

One argument might be that in such cases the link between interests and duties cannot be made, for the interests are unassignable. When rights are at stake it is always possible to say for whose sake a set of duties is imposed. If it were not possible to do so, or if one could only answer in terms of some vague generality such as "for the sake of society", then appeal to collective interests would be pointless. But the fact that benefits are collective in their scope does not show that they are indeterminate, for they may be assignable to all members of a certain class, as both Mill and MacCormick concede. Injury to class-assignable interests is not in any pejorative sense a 'purely constructive' injury. Mill's use of that term need not therefore be taken to exclude harm to collective interests; it simply cautions us from coercively interfering with people for the sake of abstractions like 'social peace' or 'community standards'. Too often when these terms are invoked the problem is not that the interests are spread out amongst a group, but that it is not possible to say of any given individual whether or not she benefits. The obstacle to grounding rights in such cases is not the publicity but the indeterminacy of the putative benefits.

A second and different source of scepticism about collective rights is substantive in character. It might be said that only our most urgent interests can ground duties in others, because duties are potentially onerous. Then, one might maintain that our most urgent needs are for individual and not collective goods. I have an urgent interest in sufficient food, but not in there being a lively artistic climate in my city. Genuine though this interest may be, it would not warrant holding others to be duty-bound to provide in some way for such a climate. Similar contrasts might be drawn between the familiar liberal rights to life, liberty, security of the person, on the one hand, and collective goods such as a clean environment, a tolerant society, or a free market on the other. With respect to the latter goods, the benefit of all is a condition of the benefit of each. Are all such collective interests different in kind from those that underpin the classical family of liberal rights?

This is very doubtful. As Denise Réaume has convincingly argued ${ }^{15}$ some collective interests are certainly urgent enough to justify holding others to be duty-bound. Consider, for example, the collective good of a disease-free environment. Many public health measures, including compulsory inoculation for certain diseases, water purification, etc. are public goods duties to supply which are adequately grounded in the vital interests that those duties serve.

14. D.N. MacCormick, Legal Right and Social Democracy (Oxford: Clarendon Press, 1982) at 142.

15. D. Réaume, "Individuals, Groups, and Rights to Public Goods" (1988) 38 Univ. Toronto L.J. 1. 
Perhaps the difficulty lies on the other side; not on the unimportance of the interests but in the burdensomeness of the duties, particularly because of the complex schemes of social cooperation that they demand. We must not make the mistake of assuming that private goods are always less burdensome to produce than public goods: there can be little doubt that it is harder to supply security of the person than it is to supply immunity from measles.

Moreover, it is no part of the general concept of rights that one has a right to $X$ only if the interest is sufficiently urgent to ground a set of duties sufficient for optimal, or even adequate, provision of $X$. It is, for example, generally thought that there is a moral right to freedom of expression. But that interest, urgent though it may be, is not sufficiently powerful to warrant holding others duty-bound to do everything necessary to secure it fully. It may stop short, for example, of complete provision of facilities. (I do not say that free expression is a negative right only, merely that there are some positive duties to encourage voice that are not adequately justified by reference to the interest in having that right.) The condition that must be satisfied is rather that it be capable of grounding some duties. So the fact that collective goods typically require social co-operation to be produced and that some duties to cooperate cannot be justified by the interest in those goods, does not show that there can be no rights to them.

Once again, we would need to distinguish a collective right so understood from a set of individual rights. Raz identifies the further necessary conditions thus: "the interests in question are the interests of individuals as members of a group in a public good and the right is a right to that public good because it serves their interest as members of the group."16 It is also necessary that "the interest of no single member of that group in that public good is sufficient by itself to justify holding another person to be subject to a duty." "'

So there is no reason of either logic or substance why the interests that ground rights cannot be collective interests, and therefore no reason to endorse the classical position that all rights are rights to private goods. One might, however, say that it is misleading to think of rights to collective goods as collective rights. They are just individual rights to collective goods and one needs no special terminology to express that. But there is a difference worth marking here, for it is not the individual interest that grounds these rights, but rather the set of linked collective interests that does so. If anything, the parsimony objection bears more directly on the view that collective rights are the rights of collective agents. One might argue that there is no need for a special term to describe what are really just two views about individuals. Some people think that only natural persons are individuals, others think that corporations, nations, tribes, etc. are too. Just as biologists might for some purposes treat a swarm of bees, or even a gene pool, as an individual, so might political theorists treat a nation or a state. Remember, their argument is not that there are ways to get rights other than through the interest-duty nexus, but rather that the requisite capacity to have such interests is more widely spread

16. Raz, supra, note 4 at 208.

17. Ibid. 
than some think. Hence, the possible economy of terminology is no argument in favour of one conception of collective rights over the other.

\section{The Political Function of Collective Rights}

Having sketched two different views of collective rights, I want to conclude by asking which, if either, is better able to fulfil the anti-individualistic ambitions of those who endorse collective rights.

I do not here wish to deny that the rights of collective agents have a place in our moral and political vocabulary. It is true that venturing down that path may mire us in the swamps of ontology and mereology: Do groups exist? Are members parts of groups? Are groups more than the sum of their members? These questions are, to say the least, difficult. In many cases we do not even have an adequate sense of what would count as an answer. But my present concern is different. I want to suggest that even after we have resolved all of these issues in a satisfactory way, the theory of collective rights as the rights of collective agents cannot fulfil the political function assigned to it. Briefly, the problem is that the collective agency approach is really a dispute about agency rather than value, so it does not reach the kind of individualism that is being complained of.

Michael McDonald gives an explicit defense of why anti-individualists should endorse collective rights in the agency sense. He argues:

there is a good reason to want community interests in general to be protected by the
community's rather than through an individual member's exercise of a right. For it is
the welfare or interests of the community that is at stake and not just the welfare of a
given member. The risks to the community's interests are increased if individual
members may on their own without prior community agreement exercise rights. The
chances of there being either a misconceived or even a mischievous exercise of rights
are increased if the power to exercise is not subject to the beneficiary's control. ${ }^{13}$

The position thus is that collective agents are in a better position to look after their interests than are the individuals that compose them, so that the community's interests should be protected by the community's rights. This confounds, I think, usefully separable questions. First, we should distinguish the question of who has (or should have) a right from the question of who should have the normative powers of exercise or waiver over it. There are sometimes good reasons for vesting these in someone other than the rightholder. Children, for example, have interests that warrant holding others dutybound to care for them. But there are obvious reasons for giving the powers of control over these rights to those most likely to act in the children's long-run interest, and thus not to the children themselves. It does not follow from the fact that something has the capacity to be a right-holder that it also has the capacity to be a right-exerciser.

Second, the thesis that community interests are not well-protected by individual rights does not, if sound, show that the community should have

18. M. McDonald, "Should Communities Have Rights? Reflections on Liberal Individualism", this issue at 232. 
rights. Animals are not well-served by human rights, but that gives no positive reason for thinking that animals have rights. Indeed, the underlying concern-that individuals may exercise their rights 'on their own without prior community agreement' remains even if we add community rights to the picture. It is removed only if individuals do not have any rights the illmotivated exercise of which could possibly harm the community's interests. Having rights never guarantees that agents will exercise them wisely or well, for the normative function of rights in moral and political argument is not to guide the choices of the right-holder, but to guide the choices of those who may be in a position to affect her interests. So McDonald's possibly correct suspicion that individual rights are not an adequate guarantee for community interests does not justify any collective rights.

Moreover, there are hard questions about what 'community' refers to in such arguments. Between 'individuals' and 'the community' there is a full panoply of collective agents. On McDonald's view, these agents can generally be relied upon to look after their own interests. But that does not show that their interests are anything other than the familiar divisible goods. Nor does it eliminate potential conflict. Cannot a corporation, a family, a church, or a nation insist on its rights at the expense of the common good? The conflict between Quebeckers and Mohawks is not softened, or widened, by the language of collective rights on each side. It is not as if there are some important moral or political considerations that are unnoticed, or are not allowed their proper significance, until this notion of collective rights is introduced.

Indeed, there is an important question of how the 'community interest' is even to be defined in circumstances where the interests of collectivities conflict. A recent and clear example of the language of collective rights gone awry is in the dispute about the signs law in Quebec. The provincial government prohibited the use of external commercial signs in English and required French signs in their place. The conventional analysis is that this was a conflict between an individual right of English Quebeckers to freedom of expression and the collective right of French Quebeckers to cultural survival. But that is an unhelpful account. First, the interest in freedom of expression is one shared by both French and English, though of course each would probably exercise that freedom in a different way. Second, the collective interest in cultural well-being of one's own group also appears on both sides of this dispute. Too often, it is thought that the conflicts that emerge with collective rights are always between rights of the collective and rights of individuals. In fact, that is merely a special case of inter-rights conflict, and there is no reason to think that the others-conflicts among individual rights, conflicts among collective rights-will disappear in its wake.

This should not be surprising. Some philosophers have proposed that we think of individual human beings as collectives, as more-or-less connected sequences of selves-for instance, the child, the adolescent, and the adult. If one thought that these prior selves had rights, and then came to regard a whole life as, at least in some respects, a collective agent, would one lose any worry one initially had about the individualism of rights? I cannot see how. One's 
view of individuals would have changed, and one would either regard the world as having different, or perhaps more, individuals than one previously did. But one would not somehow have become less individualistic. The agency conception of collective rights does not mitigate the emphasis on individualized values at all; it merely suggests that these values are more widely located that is otherwise thought ${ }^{19}$, for in addition to individual human beings it recognizes certain groups as the originators of valid claims.

Now consider rights to collective interests. On this view, it is wrong to think that only fully individuated interests can give rise to rights. It calls our attention to the collective character of certain urgent human goods and suggests that at least some of these do warrant holding others duty-bound. If the arguments outlined in Section 3 above are sound, then there is reason to doubt that the realm of rights is exhausted by the traditional individual goods of liberal theory.

Again, this is a metaphysically neater conception of collective rights, though that is not a decisive argument in its defense. But there is, now, a substantial issue of political morality to be joined, for on this view what matters urgently in human life is not merely our individualizable interests, but also our collective ones, those public goods and shared goods that are so vital to human well-being that they warrant holding others duty-bound. To promote these concerns into the realm of rights is to challenge one familiar conception about what matters in life, a conception popular in the individualist tradition of political theory.

It is important to be clear, however, about the limited scope of that challenge. It is not as if collective rights are left-wing while individual rights are right-wing, or that collective rights outweigh individual rights whenever they conflict. These are substantive matters that cannot be decided by the gross structural considerations I have raised here. Nor, is it a complete challenge. There is no way of showing that every significant non-individual good will ground collective rights.

This will be of most concern to those who want both to temper the individualism of rights theories and also to insist that morality not only includes fundamental rights but is exhausted by them. There are, however, other possibilities. Provided other normative standards are available, some of the work of defending collective concerns may, and probably should, go on in different departments of morality. My point here has simply been to contend that regarding collective agents as having the capacity to be rights-holders does nothing to allay any of the political concerns mentioned at the outset. In contrast, allowing that there may be rights to collective goods will mitigate it in some cases.

The political function of theories of collective rights is limited by the fact that they are always, to some extent, an internal critique of rights theories, one that seeks to incorporate collective moral concerns within the general model of rights. One might, however, also respond with an external critique and defend

19. This conclusion is reached on different grounds in M. Tushnet, "Law and Group Rights: Federalism as Model," in A. Hutchinson \& L. Green, eds, Law and the Commumity: the End of Individualism? (Toronto: Carswell, 1989) 276 at 277-97. 
the urgency of other kinds of moral concems in different ways: by pointing out, for example, that not all rights are important, that the public interest may sometimes properly defeat the protection of rights, and so forth. Arguments from interests, whether individual or collective, are not the only way to ground the existence of duties. A theory could of course make use of both strategies, arguing that in addition to individual rights there are both collective rights and urgent, duty-justifying, non-rights-based considerations as well. I do not think that we are able to say, in advance of the arguments, which strategy, or which combination of strategies, is the most attractive. But it seems to me that rights to collective interests, rather than the rights of collective agents, will be of more help to anti-individualists in their task. 